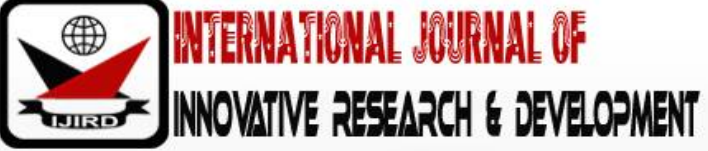

ISSN 2278 - 0211 (Online)

\section{Digital Divide in Urban Barangay Governance and Its Policy and Research Implications}

\author{
Love Jhoye M. Raboy \\ Associate Professor, Department of College of Information Technology and Computing, \\ University of Science and Technology of Southern Philippines (USTP), Philippines \\ Francis Thaise Cimene \\ Associate Professor, Department of College of Science and Mathematics \\ University of Science and Technology of Southern Philippines (USTP), Philippines
}

\begin{abstract}
:
Coming from a developing country, one can expect a digital divide not only at the individual level but even at the organizational level particularly at the smallest political unit of the Philippines called the barangay. Hence, this study was conducted with the purpose of determining the digital divide experienced in urban barangay governance with Cagayan de Oro City as the research locale. The study found out that urban barangays in Cagayan de Oro City are inadequate in terms of ICT capacities to ensure effective governance. The Management Information System is described as in its start-up stage which means that most barangay offices are in the earliest stage of ICT integration and that all components measured are in rudimentary form. However, the concerned urban barangays have the potential to serve its constituents through effective delivery of services such as the Tech4ED of the DICT among others. That is, if the local government units have the political will to comply with the required ICT components of the said project. This study then concludes that the role of ICT in barangay governance cannot be undermined. In fact, if only the barangay is fully equipped with peopleware, hardware, software, and adequate budget, urban barangay good governance cannot be farfetched.
\end{abstract}

Kevwords: Information communication technoloqy, digital divide, urban barangay governance, causal-descriptive design

\section{Background and Rationale}

"Imagine every Filipino connected to the government and all their needs at the tip of their fingers. This is the future and the future is here." This is Gov Cloud Ph's battle cry and a lot of programs and projects have been developed and proposed to make this goal a reality. Connecting the people to the government is possible through Information and Communication Technology (ICT). ICTs, in this regard, play a significant role in promoting development (Sein and Harindranath, 2004). Unfortunately, there are not enough relevant research in developing countries relative to the role of ICT in development (Pilat, 2005).

Information and Communication Technology existence has marked a share in the daily transactions for each organization may it be either a government or non-government organization. History tells that computers and internet in the Philippines has long been here since 1960's and 1990's respectively. However, only private organizations have their hands tied up with this technology. With the advancement of technology in the recent years, government organizations need to coup up with this fast-track technology. Likewise, there is now a clear and unspoken demand from the Filipino people that the government needs to embrace this new technology. Post-modern governance concept presents an idea in the lateral management of organization. In fact, postmodern good governance can be best achieved if ICT is being utilized efficiently and effectively.

The United Nations Human Rights commissioner best defined good governance by its different key attributes. These are transparency, responsibility, accountability, participation, and responsiveness. ICT is the best enablers of this different key attributes. ICT new technologies comes in handy now a days. The web and online tools, databases, cloud computing and mobile technology can be integrated to achieve good governance.

This study is particularly interested in ICT utilization at the barangay level governance of Cagayan de Oro City. The city's long-term vision of development is to be the significant development hub of the south. It envisions a city that is managed through good governance, empowering its citizenry to thrive in a highly competitive economy and a sustainable environment nurturing its diversity and multicultural heritage towards a resilient, progressive and inclusive future.

According to the National Competitiveness Council (NCC), Cagayan de Oro City also known as the "City of Golden Friendship," is ranked as one of the most competitive cities in the Philippines. The Commission on Audit hailed the city as one of the top 10 richest cities in the country, and was named as one of the 2016 Next Wave Cities for the IT-BPM industry by the IT-Business Process Association of the Philippines and the Department of Information and Communications Technology. (http:/ / www.nicp.org.ph/ index.php?option=com_content\&view=article\&id=105). However, the City Mayor's 
Term Report 2013-2016 (2016), the city government faced a myriad of problems when Mayor Moreno assumed office in July 2013. Despite economic growth, poverty and criminality persisted. It indicated that the quality of essential social services such as public education, health care and social welfare have deteriorated. Meanwhile, traffic disorder involving both motorists and pedestrians was very imminent. Flooding occurrence continue to pose grave threat to communities, especially those in low-lying and riverine areas. It further stressed that the presence of a strong private sector, the academe, business community and civil society, stakeholders' participation is practically non-existent local governance.

Nevertheless, it spelled out the city government's mission under Mayor Oscar S. Moreno's leadership articulated as follows: the empowerment of the citizenry; humane, efficient and transparent participatory governance; the delivery of services that respond to stakeholders' needs; compassionate adherence to the rule of law; and the transformation of Cagayan de Oro as the prime city of convergence in the south.

To operationalize this mission, city officials formulated the 8-Point Agenda of Cagayan de Oro City as follows: Education, Peace and Order, Alleviation of Poverty, Health, Increasing Revenue, Metropolization, Environment, Infrastructure, and Hospital Services, Agricultural Productivity, Traffic, Transportation, and Tourism. However, in the roadmap of these agenda the ICT integration is nowhere to be found.

Considering that ICT utilization is one of the prerequisites to promote efficient and effective governance, this study is conducted to determine the extent of ICT utilization at the barangay level governance. The results were used to ascertain the digital divide as experienced in urban barangay governance for policy and research implications.

\section{Framework}

This study is anchored on Good Governance in the Public Sector (Juiz, et.al., 2014) which defines public effective governance as those principles that promote good decision making and efficient use of resources. Effective and efficient service delivery (Delport, 2016) and operation with transparency and integrity characterize effective governance. Most importantly, its key principle is that entities concerned pursue public interest at all times.

One of the significant issues not only in global governance today but also in international organizations and among academic researchers is the so-called digital divide (Sciadas, 2005). The reason behind this challenge according to Guillen \& Suarez (2005) is the fact that the Internet has the ability to empower civil society not only for personal and business endeavors but also in participating in governance.

Digital divide is commonly defined as "the gap between individuals, households, businesses and geographic areas at different socio-economic levels with regard both to their opportunities to access ICTs and to their use of the Internet for a wide variety of activities" (De Haan, 2004). It is also categorized into first order and second order digital divide (Jin and Cheong, 2008). The former refers to the ICT access inequality while the latter refers to ICT use inequality (Van Dijk and Hacker, 2003). Akin to this, Wilson (2004) added distribution inequality of ICT between two or more populations.

Technologies are evolving fast and there is an apparent difficulty in reaching with a consensus of operationalizing digital divide. Internet usage is one of the most used indicators of the digital divide between countries. It does not refer exclusively to the Internet for it also refers to other important ICTs such as personal computers, cellular phones, and others in understanding issues of digital divide (Vehovar, Sicherl, Husing, and Dolnicar, 2006).

\section{Literature Review}

The comprehensive definition of digital divide can be considered as a work in progress. Hawkins (2005) stressed that despite its worldwide usage, the way researchers and practitioners conceptualize it is hardly the same. It is not only a phenomenon associated with internet access but also with its usage and benefits derived from its use (Fuchs \& Horak, 2008). According to Fuchs \& Horak (2007) "The digital divide refers to unequal patterns of material access to, usage capabilities of, and benefits from computer-based information- and communication technologies that are caused by certain stratification processes that produce classes of winners and losers of the information society, and participation in institutions governing ICTs and society." Since there is so much inequality in society, the reality of digital divide is undeniable (Servon, 2008).

Fuchs and Horak (2007) defines the three types of access to ICTs as follows: material access is the availability of hardware, software, applications, networks, and the usability of ICT devices and applications; usage and skill access is the capabilities needed for operating ICT hardware and applications, for producing meaningful online content, and for engaging in online communication and co-operation; benefit access means ICT usage that benefits the individual and advances a good society for all; institutional access is the participation of citizens in institutions that govern the Internet and ICTs, and the empowerment of citizens by ICTs to participate in political information, communication, and decision processes (Fuchs \& Horak, 2007).

Varying forms of digital divide exist not only in developing countries like the Philippines but even in developed countries such as the United States and Japan. In the study of Chakraborty and Bosman (2005), the findings revealed that ownership of personal computers displayed distribution inequalities all over United States. Meanwhile, in Japan geographic inequality in access to information and communication services is observed (Yuguchi, 2008).

It is important to note that digital divide is considered as a pressing and continuing concern since development of technologies is changing fast. With fast evolving technologies, different forms of digital divides are also emerging that include among others: gender divide, age divide, and income divide (Boje and Dragulanescu, 2003). However, the most important emerging digital divide is technological, and that is, internet access particularly the quality of connection (Servon, 2008). It is of common knowledge that broadband is important to really optimize the use of the internet for communication and information system. The Philippines is one of those countries that is affected by poor quality of internet connectivity. 


\section{Methodology}

This study made use of the descriptive research design deemed appropriate for the purpose of identifying the extent of ICT integration in urban barangay governance. This is to ascertain the digital divide for policy and research implications.

Data were obtained from 28 officials representing 28 urban barangays of Cagayan de Oro City using key informant interviews. The barangay is the basic unit of government. It is made up of at least 2000 inhabitants. It functions as the primary planning and basic services delivery unit. It also serves as a forum where people's interests and opinions on local and national issues are articulated. It likewise serves as a venue for settling neighborhood disputes. It is headed by the punong barangay, who heads the sangguniang barangay or the barangay legislative council (Garcia, 2015).

ICT in this study covers the hardware, software, peopleware, communication or connectivity. Proper protocols for the conduct of the study were followed to ensure that ethical considerations were satisfied.

The study was conducted in the four out of five growth areas of the city considered for physical development under the 2013-2022 CLUP for Cagayan de Oro City endorsed by the CDC, RDC and the city council. The said areas include: Urban expansion area \#1 (Western Urban Development Area)

This growth node covers barangays Bulua, Patag, Kauswagan, Bonbon and Bayabas. It serves as the entry and exit points from and to Laguindingan Airport and other parts of the country by air, and to the western part of Mindanao by land. This also serves as the major convergence point for people, goods and products, as well as transport service to and from other parts of the region.

\subsection{Urban Expansion Area \# 2 (West Uptown Development Area)}

This covers barangays Carmen, Canitoan, Lumbia and Pagatpat. This is envisioned to be a medium to high-density, mixed-use pedestrian friendly center with high end, low-density type of development for residential and commercial uses. This area will decongest the present major urban center/ city core and shall provide more opportunities for socioeconomic activities. The Lumbia Airport is recommended to be converted into an industrial area/ economic zone and become a major employment provider.

\subsection{Urban Expansion Area \# 3 (East-Uptown Development Area)}

This covers barangays Gusa, Indahag, Macasandig and Camaman-an. This area will have the same function as that of the West-Uptown Development Area with the presence of high-end subdivisions like the Fil-Estate Subdivision and Alegria Hills. This area is linked to the other proposed major urban centers through the Pelaez Highway that also connects to the West-Uptown Development Area.

\subsection{Urban Expansion Area \# 5 (Downtown Development Area)}

This is the existing urban center, which is expected to further transform into a high-density commercial district comprising the downtown area and barangays Carmen, Lapasan, Puntod and Macabalan.

In terms of analysis, this study limits itself to the organizational level of digital divide (Riggins \& Dewan, 2005). In this case, the urban barangays of Cagayan de Oro City. Data were analyzed using descriptive statistics particularly frequency and percent distributions. Meanwhile, research data gathered from the in-depth interviews were used to shed light on the salient findings of the study. In-depth interview is a qualitative research technique involving small number of participants (Boyce and Neale, 2006) with the aim of exploring ICT integration as part of barangay governance. Since detailed information about usage of ICT in barangay operations were needed in the study, this technique of data collection is considered appropriate.

\section{Results and Discussion}

\subsection{Profile of Respondents and the Barangay}

Table 1 presents the profile of the respondents and the barangay included in the study. Data show that the respondents interviewed were mostly female (60.7\%), between the ages 24 to 43 years old (57.1\%), with the position of barangay secretary (53.6\%), and have served the barangay for 5 years and below (46.4\%) and 6 to 10 years (32.1\%). As to the population of the barangay, data show that $39.3 \%$ of the barangays have less than 1,000 population while $21.4 \%$ have $1,000-10,000$ and $21,000-30,000$ respectively. 


\begin{tabular}{|c|c|c|}
\hline \multicolumn{1}{|c|}{ Profile } & Frequency & Percent \\
\hline Gender & 11 & 39.3 \\
Male & 17 & 60.7 \\
Female & 28 & 100.0 \\
\hline Total & & \\
\hline Age $24-33$ & 9 & 32.1 \\
34-43 & 7 & 25.0 \\
44-53 & 5 & 17.9 \\
54-63 & 6 & 21.4 \\
64 and above & 1 & 3.6 \\
Total & 28 & 100.0 \\
\hline Position in the Barangay & Frequency & Percent \\
Local Chief Executive & 1 & 3.6 \\
Secretary & 15 & 53.6 \\
Treasurer/ Bookkeeper & 6 & 21.4 \\
Brgy. Councilor & 4 & 14.3 \\
Others & 2 & 7.1 \\
Total & 28 & 100.0 \\
\hline Years of Service in the Barangay & Frequency & Percent \\
5 years and below & 13 & 46.4 \\
6-10 years & 9 & 32.1 \\
11-15 years & 1 & 3.6 \\
16-20 years & 3 & 10.7 \\
21 years and above & 2 & 7.1 \\
Total & 28 & 100.0 \\
Population of the Barangay & Frequency & Percent \\
Less than 1,000 & 11 & 39.3 \\
1,000-10,000 & 6 & 21.4 \\
21,000-20,000-30,000 & 1 & 3.6 \\
31,000 and above & 3 & 21.4 \\
No Response & 10.7 \\
Total & & 3.6 \\
Tab1:Profile & 100.0 \\
\hline
\end{tabular}

Table 1: Profile of the Respondents and the Barangay

\subsection{ICT Profile of the Barangays Included in the Study}

Table 2 shows the ICT profile of the barangays included in the study and data revealed that only a little over half or $57.1 \%$ have internet connection. Among those with internet connectivity, $75.0 \%$ tapped PLDT as the internet provider and remotely followed by Globe at 12.5\%. The other internet providers are Smart (1 or 6.3\%) and Bayantel (1 or 6.3\%). With regard to speed, $75.0 \%$ have $3 \mathrm{mbps}$ and $6.3 \%$ have 1,2,15, and 50 mbps respectively. Almost all (89.3\%) barangays have only one person who maintains the ICT infrastructure at an on-call basis. Only one barangay has 2 maintenance personnel and one with 3 personnel with job order item.

Moreover, $82.1 \%$ of the barangays have 1 to 5 workstations while 2 or $7.1 \%$ have $6-10$ and more than 10 workstations respectively. One barangay has no workstation. One or more of these hardware resources were procured using the budget from the barangay while $21.4 \%$ were acquired through the Office of the Congressman and $7.1 \%$ through non-government organization.

Half of the computer units were purchased recently (50.0\%) while 39.3\% were purchased in 2014-2015 and earlier than 2013 respectively. Also, most of the barangays' CPU model were old versions of Intel (71.4\%) while the rest are Intel Dual Core (10.7\%), Intel Core 13 (21.4\%), and Intel Core 15 (7.1\%). As to memory, 57.1\% have 2GB, 25.0\% 4 GB while there are still 2 barangays with less than 2 GB (7.1\%) memory of their computer units.

Furthermore, all barangays have hard disk drive/ capacity of 465 GB (100.0\%) while 2 or $7.1 \%$ have 256 GB and 1 TB respectively. Only one barangay has licensed Microsoft Operating System while the rest are without license. As to Office Productivity Software Used: $96.4 \%$ use Word, $85.7 \%$ use Excel, $42.9 \%$ use Powerpoint, 28.6\% use e-mail, and only 1 or $3.6 \%$ use web browser. Also, only one barangay uses online web portal to disseminate information to its stakeholders. 
Word is mainly used for making notices, memorandum circulars, and minutes of meetings among others. Meanwhile, EXCEL is used in managing financial data of the barangay.

\begin{tabular}{|c|c|c|}
\hline ICT Profile & Frequency & Percent \\
\hline Internet Connectivity & Frequency & Percent \\
\hline With Internet Connection & 16 & 57.1 \\
\hline Without Internet Connection & 12 & 42.9 \\
\hline Total & 28 & 100.0 \\
\hline Internet Provider & Frequency & Percent \\
\hline PLDT & 12 & 75.0 \\
\hline Globe & 2 & 12.5 \\
\hline Smart & 1 & 6.3 \\
\hline Bayantel & 1 & 6.3 \\
\hline Total & 16 & 100.0 \\
\hline Speed & Frequency & Percent \\
\hline $1 \mathrm{mbps}$ & 1 & 6.3 \\
\hline $2 \mathrm{mbps}$ & 1 & 6.3 \\
\hline $3 \mathrm{mbps}$ & 12 & 75.0 \\
\hline $15 \mathrm{mbps}$ & 1 & 6.3 \\
\hline $50 \mathrm{mbps}$ & 1 & 6.3 \\
\hline Total & 16 & 100.0 \\
\hline Number of people who maintains the ICT infrastructure & Frequency & Percent \\
\hline 1 & 25 & 89.3 \\
\hline 2 & 1 & 3.6 \\
\hline 3 & 1 & 3.6 \\
\hline Total & 28 & 100.0 \\
\hline Hardware Profile & Frequency & Percent \\
\hline Number of Workstation & & \\
\hline $1-5$ & 23 & 82.1 \\
\hline $6-10$ & 2 & 7.1 \\
\hline 10 and above & 2 & 7.1 \\
\hline None & 1 & 3.6 \\
\hline Total & 28 & 100.0 \\
\hline Donors/ Sponsors of hardware resources & Frequency & Percent \\
\hline From the budget of the barangay & 28 & 100.0 \\
\hline From the Office of the Congressman & 6 & 21.4 \\
\hline $\begin{array}{l}\text { From non-government organization } \\
\text { Note: Multiple Response }(\mathrm{N}=28)\end{array}$ & 2 & 7.1 \\
\hline Technical characteristics & Frequency & Percent \\
\hline & 11 & 39.3 \\
\hline Year of Purchase & 11 & 39.3 \\
\hline Earlier than 2012-2013 & 14 & 50.0 \\
\hline $\begin{array}{l}2014-2015 \\
2016-2017\end{array}$ & & \\
\hline $\begin{array}{l}2016-2017 \\
\text { Note: Multiple Response (N=28) }\end{array}$ & Frequency & Percent \\
\hline & & 71.4 \\
\hline CPU Model & 20 & 10.7 \\
\hline Old versions of Intel & 3 & 21.4 \\
\hline Intel Dual Core & 6 & 7.1 \\
\hline Intel Core 13 & 2 & \\
\hline Intel Core 15 & & \\
\hline Note: Multiple Response ( $\mathrm{N}=28$ & & Percent \\
\hline Memory & Frequency & 7.1 \\
\hline Less than 2 GB & 2 & 57.1 \\
\hline $2 \mathrm{~GB}$ & 16 & 25.0 \\
\hline $4 \mathrm{~GB}$ & 7 & \\
\hline
\end{tabular}




\begin{tabular}{|c|c|c|}
\hline ICT Profile & Frequency & Percent \\
\hline Note: Multiple Response (N=28) & $\begin{array}{c}\text { Frequency } \\
2 \\
\end{array}$ & $\begin{array}{c}\text { Percent } \\
7.1 \\
\end{array}$ \\
\hline $\begin{array}{c}\text { Hard disk drive/ capacity } \\
256 \mathrm{~GB} \text { and below } \\
465 \mathrm{~GB} \\
1 \mathrm{~TB} \\
\text { Note: Multiple Response }(\mathrm{N}=28)\end{array}$ & $\begin{array}{c}28 \\
2\end{array}$ & $\begin{array}{c}100.0 \\
7.1\end{array}$ \\
\hline $\begin{array}{c}\text { Software Profile } \\
\text { Operating System Used } \\
\text { Microsoft without license } \\
\text { Microsoft with license } \\
\text { Note: Multiple Response }(\mathrm{N}=28)\end{array}$ & $\begin{array}{c}\text { Frequency } \\
27 \\
1\end{array}$ & $\begin{array}{c}\text { Percent } \\
\\
96.4 \\
3.6\end{array}$ \\
\hline $\begin{array}{c}\text { Office Productivity Software Used } \\
\text { Word } \\
\text { Excel } \\
\text { Powerpoint } \\
\text { e-mail } \\
\text { Web browser } \\
\text { Note: Multiple Response }(\mathrm{N}=28)\end{array}$ & $\begin{array}{c}27 \\
24 \\
12 \\
8 \\
1\end{array}$ & $\begin{array}{c}96.4 \\
85.7 \\
42.9 \\
28.6 \\
3.6\end{array}$ \\
\hline $\begin{array}{c}\text { Other Software } \\
\text { Online web portal for the barangay } \\
\text { Note: Multiple Response }(\mathrm{N}=28)\end{array}$ & 1 & 3.6 \\
\hline Management Information System & Frequency & Percent \\
\hline $\begin{array}{l}\text { Start-Up } \\
\text { Developing } \\
\text { Expanding } \\
\text { Mature } \\
\text { Total }\end{array}$ & $\begin{array}{c}27 \\
1 \\
0 \\
0 \\
28\end{array}$ & $\begin{array}{c}96.4 \\
3.6 \\
0.0 \\
0.0 \\
100.0\end{array}$ \\
\hline
\end{tabular}

Table 2: ICT Profile of the Barangay

With regard to the barangays' Management Information System, 96.4\% can be described as in a Start-Up Stage which means that the barangay office is in the earliest stage of ICT integration and that all components measured are in rudimentary form or non-existent. Indicators used include having: complete MS policies, procedures, and manuals; computerized information system; competent and well-trained MS unit/ personnel; efficient MIS that produces reports and is compliant with government standards; practices Green Technology and Information (guidelines on use of communications, documents, manuals, etc.); and the implementation of IT Risk Management System. Only one barangay is in Developing Stage which means that it is developing some ICT capacities and this refers to Barangay Carmen.

Barangay Carmen is the largest barangay of Cagayan de Oro City. It has an area of 566,311 hectares and inhabited by 72,000 people. Its 13,000 households are distributed to 73 zones. Of the 73 zones, zones 2,4,5,7,9 are river bank zones. Zone 3 is the commercial center where Carmen Market is situated (http:/ / www.brgycarmen.ph/ barangay-profile/).

Among the barangays covered in the study, only Barangay Carmen showed relatively extensive use of ICT with 50 mbps speed of internet connectivity servicing their Tech4ED Center and web portal used to disseminate information to its stakeholders. Three personnel manned the said center.

The Department of Information and Communication Technology for Economic Development or Tech4ED is a project component of the ICT Office of DOST that aims to harness ICT to enable, empower and transform society towards creating an inclusive, integrated and equitable countryside. It offers three main services namely: eEduSkills, eAssist, and eGovServ.

eEduSkills aims to deliver e-learning on demand to address the education divide. It focuses on the following: Alternative Learning System (High School diploma for out of school youth or OSY and adults); Learning English Application for Pinoys or LEAP that aims to improve English communication skills in preparation for IT-BPM industry; Skills Training to acquire skills and competencies to start a small business or to get employed; Values Character Formation to enable OSY and students to uphold Filipino values; and Rotary e-Library which is an online library to access various books.

On the other hand, eAssist aims to enable women, PWDs, OFW, Senior Citizens, and Indigenous People through access to special content and these include: ICT for digital literacy (upgrade digital competencies for employment and entrepreneurial opportunities); ICT for financial literacy (learn how to save, spend and invest money); ICT for career development (develop competencies relevant to an industry for higher grade jobs); and ICT for entrepreneurs (learn how to start your own business and use ICT to expand market reach). 
Meanwhile, eGovServ provides direct government services in rural communities and these include: overseas Filipino online portal, BIR, PRC, Birth Certificate, Driver's License, DTI Registration, Social Security, Overseas Employment Certificate, Voter's Registration, PAGIBIG, Passport, PhilHealth, GSIS, Postal ID, Phil Post Track and Trace.

However, based on site observation and interviews with the key informants, not all features of the Tech4ED are available to their constituents. At the time of the study, only the following services were used: Alternative Learning System, Learning English Application for Pinoys, NBI Clearance application, passport, and birth certificate among others. The center also encountered several constraints that affected their services such as: lack of facilities (they only have two work stations); lack of manpower (three personnel); and doing other quasi-jobs specifically encoding household data for the barangay profiling.

\section{Implications to Policy and Research}

One of the most important goal of local governance is the effective delivery of services that would redound to the common good of the people. Crucial to this role is the ICT utilization. To reap the benefits of ICT utilization, it is evident from the findings of this study that the government needs to invest in ICT infrastructures. Given that government funds are insufficient to address this need, barangay officials should lobby at the city level for assistance not only financially but also in mobilizing private and public partnership. So far, Barangay Carmen was successful in this endeavor and the rest could benchmark from it.

Standards of good governance promote usage of ICT in serving the people. Governance as used in the study refers to the exercise of political, economic, and administrative authority in the management of a country's affairs at all levels specifically at the barangay level (Garcia, 2015). It implies the need for the urban barangays to pass a legislation that would align ICT functions in achieving the local government units' goals and objectives. The findings also imply that urban barangays should collaborate with agencies particularly the Department of Information and Communications Technology for technical support in implementing projects such as Tech4Ed that would best serve the people.

Other policies relative to modernization of urban barangay services through ICT integration must be passed. The essence of these policies must be to address the digital divide not only at the organizational level but even at the inter-agency level. Programs and projects of the government such as the DICT will only be successful through the synergistic efforts and collective stakeholder management. This implies the need for strong cooperation and coordination among stakeholders in order to promote complementary and coherent programs.

Moreover, a study must be conducted on how to translate high-impact programs of the government to the barangay level. Also, with the barangay sector's increasing planning and policy support needs, it implies the need for the academe to use its research capacity to narrow the gap.

In addition, the academe could pursue studies that would determine the extent of dependence of the local government unit (in this context the barangay) on the Internet for service delivery and government operations. It is only then that policies can be designed to lessen the gap of the digital divide.

\section{Conclusion and Recommendations}

From the results of the study, this study came up with three conclusions. First, it concludes that the role of ICT in barangay governance cannot be undermined. In fact, if only the barangay is fully equipped with peopleware, hardware, software, and adequate budget, barangay good governance cannot be farfetched. Second, urban barangays in Cagayan de Oro City is inadequate in terms of ICT capacities to ensure effective governance. Third, the urban barangays have the potential to serve its constituents through the Tech4ED of the DICT, however, they need to be compliant to the required ICT components.

From the foregoing findings and conclusions, this study made the following recommendations:

- There is a need for urban barangays in Cagayan de Oro City to consider developing their ICT capacities for effective governance. This requires budget allocation and strong partnerships with other government and nongovernment organizations.

- The Government Cloud (Gov Cloud) is "central to the objective of setting up systems and services that would enable efficient operations". For instance, servers, storage devices, networking equipment, and software found in the cloud help improve government processes and delivery of services to the people. The government also saves money this way because services are shared by agencies. This means that one agency can take advantage of the same resources needed by another agency. Hence, it is recommended that barangay officials should take advantage of cloud technology.

- The Department of Interior and Local Government (DILG) in 2014 mandated all LGUs including the barangay LGUs to commit on its transparency and accountability project. One of the thrusts of the department is to increase the web presence of LGUs or the use of cloud computing to display their transparency seal. In relation thereof, there is a need for the barangay LGUs to optimize the use of internet and web-based technologies in managing barangay operations.

\section{References}

i. City Mayor's Term Report 2013-2016

ii. Billon, M., Marco, R., \& Lera-Lopez, F. (2009). Disparities in ICT adoption: A multidimensional approach to study the cross-country digital divide. Telecommunications Policy, 33(10-11), 596-610.

iii. Boje, C., \& Dragulanescu, N. G. (2003). “Digital Divide” in Eastern European Countries and its Social Impact. age, 8,1 . 
iv. Boyce, C., \& Neale, P. (2006). Conducting in-depth interviews: A guide for designing and conducting in-depth interviews for evaluation input.

v. Chakraborty, J., \& Bosman, M. M. (2005). Measuring the digital divide in the United States: Race, income, and personal computer ownership. The Professional Geographer, 57(3), 395-410.

vi. De Haan, J. (2004). A multifaceted dynamic model of the digital divide. It \& Society, 1(7), 66- 88.

vii. Delport, P. M., Von Solms, R., \& Gerber, M. (2016, May). Towards corporate governance of ICTinlocal government. In IST-Africa Week Conference, 2016 (pp. 1-11). IEEE.

viii. Fuchs, C., \& Horak, E. (2007). Information capitalism and the digital divide in Africa. Masaryk UJL \& Tech., 1, 11.

ix. Fuchs, C., \& Horak, E. (2008). Africa and the digital divide. Telematics and informatics, 25(2), 99-116.

x. Garcia, C. (2015). Philippine Government and Constitution. Mandaluyong City: Books Atbp Publishing Corp.

xi. Guillén, M. F., \& Suárez, S. L. (2005). Explaining the global digital divide: Economic, political and sociological drivers of cross-national Internet use. Social forces, 84(2), 681-708.

xii. Hawkins, S. (2005). Beyond the digital divide: Issues of access and economics. Canadian journal of information and library science, 29(2), 171-189.

xiii. Jin, J., \& Cheong, A. W. H. (2008). Measuring digital divide: The exploration in Macao. Observatorio (OBS*), 2(3).

xiv. Juiz, C., Guerrero, C., \& Lera, I. (2014). Implementing good governance principles for the public sector in information technology governance frameworks. Open Journal of Accounting, 3(01), 9.

xv. Pilat, D. (2005). The ICT productivity paradox. OECD economic studies, 2004(1), 37-65.

xvi. Riggins, F. J., \& Dewan, S. (2005). The digital divide: Current and future research directions. Journal of the Association for information systems, 6(12), 4 .

xvii. Sciadas, G. (2005). From the digital divide to digital opportunities.

xviii. Seal of Good Local Governance (Tab B Technical Notes: Indicator Reference)

xix. Sein, M. K., \& Harindranath, G. (2004). Conceptualizing the ICT artifact: Toward understanding the role of ICT in national development. The Information Society, 20(1), 15-24.

xx. Servon, L.J. (2008). Bridging the digital divide: Technology, community and public policy.John Wiley \& Sons.

xxi. Van Dijk, J., \& Hacker, K. (2003). The digital divide as a complex and dynamic phenomenon. The information society, 19(4), 315-326.

xxii. Vehovar, V., Sicherl, P., Hüsing, T., \& Dolnicar, V. (2006). Methodological challenges of digital divide measurements. The information society, 22(5), 279-290.

xxiii. Yuguchi, K. (2008). The digital divide problem: An economic interpretation of the Japanese experience. Telecommunications Policy, 32(5), 340-348.

xxiv. http:/ / www.unescap.org/ sites/ default/ files/good-governance.pdf

xxv. http:// www.brgycarmen.ph/ barangay-profile/

xxvi. http:// www.nicp.org.ph/index.php?option=com_content\&view=article\&id=105 